\title{
THE EFFECT OF SAPPAN WOOD (Caesalpinia sappan L.) EXTRACT ON BLOOD GLUCOSE LEVEL IN WHITE RATS
}

\author{
Saefudin $^{1 *}$, Gunawan Pasaribu ${ }^{2}$, Sofnie $^{3}$ and Efrida Basri ${ }^{2}$ \\ Received : 9 January 2013, Accepted : 19 February 2014
}

\begin{abstract}
Sappan wood or kayu secang (Caesalpinia sappan L.) was reported of having medicinal properties, such as natural antioxidant, relieve vomiting of blood, and mix of ingredients for malaria drugs. The research was conducted to study the influence of ethanol extract from sappan wood on blood glucose level of white rats. The study of the blood glucose level in rats was carried out by using glucose tolerance method. It was measured by Refloluxs (Accutrend GC) with Chloropropamide $50 \mathrm{mg} / 200 \mathrm{~g} \mathrm{BW}$ (Body weight) as positive control. The ethanol extracts were used in various concentrations $10,20,30,40$ and $50 \mathrm{mg} / 200 \mathrm{~g}$ BW per-oral and was observed every hour, beginning one hour before to 7 hours after the extract being administered. The results showed that treatment of ethanol extract of sappan wood by administer doses gave remarkable effect on the blood glucose level in white rat. It reduced the glucose level in the blood compared to the negative and positive control. Treatment of dose $30 \mathrm{mg} / 200 \mathrm{~g} \mathrm{BW}$ gave similar effect to positive controls, while a dose of $50 \mathrm{mg} / 200 \mathrm{~g} \mathrm{BW}$ gave lower blood glucose level $(93 \mathrm{mg} / \mathrm{dl}$ ) than the positive controls.
\end{abstract}

Keywords: Sappan wood, ethanol extract, blood glucose level, white rat

\begin{abstract}
ABSTRAK
Kayu Sappan atau kayu secang (Caesalpinia sappan L.) dilaporkan memiliki banyak manfaat sebagai tanaman obat, misalnya untuk antioksidan alami, meredakan muntah darah, dan bahan-bahan campuran untuk obat malaria. Penelitian ini bertujuan untuk mengetahui pengaruh ekstrak etanol dari kayu sappan pada kadar glukosa darah tikus putih. Tingkat glukosa darah pada tikus putih dilakukan dengan menggunakan metode toleransi glukosa. Ini diukur dengan Refloluxs (Accutrend GC) dengan kloropropamida $50 \mathrm{mg} / 200 \mathrm{~g}$ BB (berat badan) sebagai kontrol positif. Ekstrak etanol yang digunakan dalam berbagai konsentrasi 10, 20, 30, 40 dan $50 \mathrm{mg} / 200 \mathrm{~g}$ BB per-oral dan diamati setiap satu jam dan dimulai satu jam sebelum sampai 7 jam setelah ekstrak diberikan. Pemberian ekstrak $30 \mathrm{mg} / \mathrm{kg}$ BB tidak berbeda nyata dengan kontrol positip, sedang pemberian ekstrak $50 \mathrm{mg} / 200 \mathrm{gBW}$ menurunkan kadar glukosa darah $(93 \mathrm{mg} / \mathrm{dl}$ ) dibandingkan dengan kontrol positif.
\end{abstract}

Kata kunci: Kayu secang, ekstrak etanol, kadar glukosa darah, tikus putih

\footnotetext{
${ }^{1}$ Research Center for Biology - Indonesian Institute of Science. Bogor

${ }^{2}$ Center for R\&D on Forestry Engineering and Forest Product Processing Bogor

${ }^{3}$ National Atomic Energy Agency. Jakarta

*Corresponding author: saefudin@email.com
} 


\section{INTRODUCTION}

Indonesian forests provide more than 9,606 species of medicinal plants (Pranoto, 1999). Most of them are native to Indonesia and many of the plants are endemic (Walujo, 2008). The high diversity of the plant species also has a great potential for the discovery of bioactive compounds they contain. Several studies have successfully revealed the antioxidant potential of some Indonesian plants (Hakim et al., 2008; Rohman et al., 2006; Amrun and Umiyah, 2005; Praptiwi et al., 2006). Three criteria must be fulfilled when extracting plants to medicine materials, i.e. quality, safety and efficacy. Advanced research must be done until the discovery of effective and simple drugs (Chairul, 2003).

Sappan wood or kayu secang (Caesalpinia sappan L.) is one of the traditional medicine materials. This species is a type of flowering tree in the group of the Fabaceae legume family. Sappan wood is native to Southeast Asia and the Malay archipelago. Common names of sappan are patanga-chekke sappanga (Kanada name) and sumu (Japanese). Sappan belongs to the same genus or synonym with Caesalpinia echinata or braziel wood (C. echinata), and was originally called "brezel wood" in Europe (Anonymous, 1998; Xu and Lee, 2004). Furthermore, this wood was a major trading goods during the $17^{\text {th }}$ century, when it was exported from Southeast Asian nations (especially Siam) to Japan.

The sappan plant is being used worldwide for a large number of traditional medicinal purposes. This plant produces brazilin that is found to be responsible for several of its biological activities (Badami et al., 2004). Modern day research confirmed it's cytotoxic from heartwood (Badami et al., 2003), antitumor from part of stem and heartwood (Dhawon et al., 1980; Itokawa et al., 1990 in Badami et al., 2004), anti-inflammatory from heartwood (Hikino et al., 1977 in Badami et al., 2004), anti-coagulant properties (Takaoka and Tagakaki, 1995), and blood vomiting cure and drug treatment after child birth (Aulia, 2002).
According to Aviratnant and Pongpan (1983) and Yadava et al. (1978) in Badami et al. (2004), the essential oil obtained from the leaves, the 95\% ethanol and water extracts of the wood showed strong antibacterian activity againts Bacillus subtilis, Staphylococcus aureus, Salmonella typhosa and Escherichia coli. Prawirosujanto (1977) and Sugati (1981) said that the bark of this plant had been used for folk medicine as anti-diarrhea, anti-microbial, expectorant, anti-pyretic, cataract, and tonic. $\mathrm{Xu}$ and Lee (2004) reported that brazilin from C. sappan is antibacterial and it has the potential to be developed into an antibiotic.

This paper studies the potential use of sappan wood for reducing blood glucose level in white rats. The analysis was carried out to see the influence of ethanol extract from sappan wood on blood glucose level of white rats.

\section{MATERIAL AND METHOD}

\section{A. Plant Materials and Experimental Animals}

1. Sappan wood (Caesalpinia sappan L.) was collected from Kemangkon village, Purbalingga, Central Java and was identified at the Herbarium Bogoriense, Research Center for Biology, Cibinong. Authentic specimen was deposited at the same Institution.

2. The experimental animals used were 2.5 to 3 months male white rats (Ratus ratus) Winstar strain of $200-300 \mathrm{~g}$ weight. Before being tested the animals were fed for 14 days to get the expected weight (Malole and Purnomo, 1989).

\section{B. Sample Preparation}

The preparation of samples and the testing procedures in the experiment used the Taylor Method (Chairul, 2003).

\section{The sappan wood extract}

Preparation of extract : $1 \mathrm{~kg}$ powder of air dried sappan wood was macerated by 95\% ethanol for 24 hours, until the solvent covered the surface of the plant material. 
After 24 hours, the filtrate was concentrated under vacuum rotary evaporator. This work was repeated 2 or 3 times until the colorless solvent was obtained. Filtrate was combined and concentrated. Then, the extracts were dried by freeze dryer to get dry sappan extracts.

\section{The glucose suspension}

2.1. $1 \% \mathrm{CMC}$ suspension

$1 \mathrm{~g} \mathrm{CMC}$ was balanced on watch glass, developed in mortar by hot water and grinded until it was homogenous and 100 $\mathrm{ml}$ purified water was added.

2.2. $1 \%$ glucose stock solution

$1 \mathrm{~g}$ glucose stock solution anhydrate was put into a $100 \mathrm{ml}$ volumetric flask, 50 $\mathrm{ml}$ aquadest was added, it was shaken and $100 \mathrm{ml}$ aquadest was added, and than it was shaken well until the glucose solved. The glucose solution from the $100 \mathrm{ml}$ volumetric flask was removed to a $150 \mathrm{ml}$ beaker glass, $2 \%$ active carbon was added, then shaken well and heated for 30 minutes on water bath, then filtered and kept in the infuse bottle.

2.3. Standard glucose solution

$1 \%$ glucose stock solution (2.2) was pipetted and put into a $100 \mathrm{ml}$ volumetric flasks, and $100 \mathrm{ml}$ aquadest purified water was added to each volumetric flask, shaken well and than homogenized. This was done to obtain glucose concentrations of $50,100,200$ and $400 \mathrm{mg} / \mathrm{dl}$ in each of the four $100 \mathrm{ml}$ vials respectively.

2.4. $100 \%$ glucose injection solution

$100 \mathrm{~g}$ glucose monohydrate was put in a $100 \mathrm{ml}$ volumetric flask, $50 \mathrm{ml}$ aquadest was added and shaken well to become homogenous and then $100 \mathrm{ml}$ aquadest was added. Filtered and removed to 200 $\mathrm{ml}$ vial and sterilized in autoclave at $120^{\circ} \mathrm{C}$ for 20 minutes.

\section{Treatment Schedule}

\section{Testing extracts}

The ethanol extract was treated with various concentrations i.e. 10, 20, 30, 40 and $50 \mathrm{mg} / 200 \mathrm{~g} \mathrm{BW}$ (Body Weight).

\section{Preliminary testing}

Preliminary testing was aimed to get the normal glucose level in the blood of the rat when suffering hyperglycemic condition, after administering a $100 \%$ glucose solution and various concentrations of sappan extracts i.e. 50,100, 200 and $400 \mathrm{mg} / \mathrm{dl}$ by intravenous injection in the tail literal vena (Table 1).

\section{Glucose tolerance testing}

Glucose tolerance testing had been carried out by administrating 100\% glucose solution with a dose of $0.1 \mathrm{~g} / 200 \mathrm{~g}$ BW, which was added orally. Each group consisted of six testing animals (rats), The extract of sappan wood was administered by various doses: 10 , 20, 30, 40 and $50 \mathrm{mg} / 200 \mathrm{~g} \mathrm{BW}$, respectively and destilated water was used as the negative control (K -), while chlorpropamide $50 \mathrm{mg} / 200$ $\mathrm{g} \mathrm{BW}$ as the positive control $(\mathrm{K}+)$. Blood glucose level in rats was measured 1 hour before to seven hours after the treatment.

Blood was taken via tail venous, centrifuged

Table 1. Preliminary testing of extract in white rats

\begin{tabular}{ccccccccc}
\hline Control & \multicolumn{8}{c}{ Glucose level in blood after treatment } \\
\hline+ & + & + & + & + & + & + & + & + \\
-1 & 0 & 1 & 2 & 3 & 4 & 5 & 6 & 7 \\
\hline
\end{tabular}

Note:

$-1=$ Glucose level in blood when fasting

$0=$ Glucose level in blood in treatment [glucose, extracts, Negative control $(-)$, positive control $(+)$ ]

1 to $7=$ Glucose level in blood after treatment 
and one drop of blood serum was dropped on glucose strip test and it was let for drying for one minute. Measuring the glucose level was done by Reflolux S (Accutrend GC). The data of blood glucose level was calculated by statistical analysis (ANOVA) by making the correlation curve of glucose level versus period (time). From the curve the "Area Under the Curve 0-7 or AUC0-7 " could be calculated with accuracy for each testing groups of animals $(\mathrm{P}=<0.05)$ (Sudjana, 1982).

\section{RESULT AND DISCUSSION}

Theblood glucoselevel of each testinganimal after administering glucose solution (100\%) with various doses, i.e. 50, 100, 200, and 400 $\mathrm{mg} / \mathrm{dl}$ via tail literal venous on hyperglycemic condition were measured and calculated. The results showed that the blood glucose level in testing white rat animals increased with the increase of the doses. The blood glucose level on testing animals increased to 49; 103.83; 196.50 and $374.70 \mathrm{mg} / \mathrm{dl}$, respectively (Table 2). Hyperglycemia conditions of the blood of white rats was most striking when given 100\% glucose solution at a dose of $400 \mathrm{mg} / \mathrm{dl}$, the average increase in glucose level was 7 times higher than with $50 \mathrm{mg} / \mathrm{dl}$.
The results of the determination of the time interval of hyperglycemic condition in rat $(\mathrm{mg} /$ dl) showed the different blood glucose level in testing animals. The average blood glucose level was $145 \mathrm{mg} / \mathrm{dl}$. The hyperglycemic condition was reached in 3 hours after the treatment (Table 3).

It appears glucose tolerance by administering $100 \%$ glucose solution at a dose of $0.1 \mathrm{~g} / 200$ $\mathrm{g}$ BW intravenously. Rats increased blood glucose levels and hyperglycemic conditions occur. Blood glucose tolerance also occured after treatment of the extract that is $10,20,30$, 40 , and $50 \mathrm{mg} / 200 \mathrm{~g}$ BW. Observations during the 4-6 hours after treatment, the rats were in hyperglycemic conditions, but the average blood glucose adapt to the normal condition.

Differences were seen in the rats between control (-1) and fasting conditions given aquadest added with chlorpropamide drugs $50 \mathrm{mg} / 200 \mathrm{gr}$ body weight (Table 3). The time interval required was 2-3 hours for adjustment after the food was absorbed (ingestion) by administering 100\% glucose solution. After that time the blood glucose levels rose from an average of (114-117) $\mathrm{mg} / \mathrm{dl}$ when fasting to $(137-152) \mathrm{mg} / \mathrm{dl}$ at the time of hyperglycemic. The condition of blood glucose after extract treatment and when anti-diabetic drugs

Table 2. Preliminary recovery of glucose level in blood of testing animals by Reflolux

\begin{tabular}{rrrrr}
\hline \multirow{2}{*}{ No } & \multicolumn{4}{c}{ Glucose level $(\mathrm{mg} / \mathrm{dl})$} \\
\cline { 2 - 5 } & 50 & 100 & 200 & 400 \\
\hline 1 & 47 & 100 & 208 & 387 \\
2 & 57 & 104 & 166 & 362 \\
3 & 50 & 114 & 199 & 368 \\
4 & 48 & 99 & 203 & 373 \\
5 & 49 & 103 & 189 & 376 \\
& 6 & 106 & 194 & 382 \\
\hline Average & 47 & 103.83 & 196.50 & 374.70 \\
\hline SD & 2.08 & 5.55 & 7.67 & 8.32 \\
\hline Recovery (\%) & 98.00 & 103.83 & 98.25 & 93.68 \\
\hline CV (5) & 5.70 & 5.34 & 3.90 & 2.22 \\
\hline
\end{tabular}

Note $: \mathrm{SD}=$ Standard deviation, $\mathrm{CV}=$ Coeficient of variation, $\mathrm{N}=3$ 
Table 3. Determination of the time interval of hyperglycemic condition in rat $(\mathrm{mg} / \mathrm{dl})$

\begin{tabular}{crrrr}
\hline \multirow{2}{*}{ Periods (hours) } & \multicolumn{3}{c}{ Groups } & \multirow{2}{*}{ Average } \\
\cline { 2 - 4 } & 1 & 2 & 3 & $116 \mathrm{a}$ \\
\hline-1 & 114 & 117 & 117 & $130 \mathrm{ab}$ \\
0 & 124 & 137 & 129 & $135 \mathrm{~b}$ \\
1 & 130 & 140 & 135 & $141 \mathrm{bc}$ \\
2 & 137 & 144 & 142 & $145 \mathrm{c}$ \\
3 & 138 & 152 & 145 & $127 \mathrm{ab}$ \\
\hline 4 & 121 & 132 & 128 & $120 \mathrm{a}$ \\
\hline 5 & 113 & 127 & 120 & $114 \mathrm{a}$ \\
\hline 6 & 108 & 120 & 114 & $110 \mathrm{a}$ \\
\hline 7 & 105 & 115 & 110 &
\end{tabular}

Note: The average value followed by the same letters were not significantly different

chlorpropamide was added, dropped to an average of (124-137) mg/dl

The results of the average blood glucose level in testing animals after treatment (in $\mathrm{mg}$ / dl) gave different levels it depended on the doses of the extracts. There was a difference in the blood glucose level in hyperglycemic conditions between control groups and fasting groups (-1) and extract treatment groups. Negative control groups showed an average blood glucose level of $145 \mathrm{mg} / \mathrm{dl}$ three hours after treatment and groups II to VI (extract 10-50 mg/200 g BW) showed a decrease of the blood glucose level to $100-137 \mathrm{mg} / \mathrm{dl}$, while the level of the positive control was $102 \mathrm{mg} / \mathrm{dl}$. Those results showed that treatment of ethanol extract of sappan wood by administer doses gave a remarkable effect on blood glucose level in rat and also reduced the glucose level in blood compared to negative control and positive control. Treatment with a dose of $30 \mathrm{mg} / 200 \mathrm{~g} \mathrm{BW}(103 \mathrm{mg} / \mathrm{dl})$ gave a similar effect as the positive control (102 $\mathrm{mg} / \mathrm{dl}$ ), while a dose of $50 \mathrm{mg} / 200 \mathrm{~g} \mathrm{BW}$ gave lower blood glucose level $(93 \mathrm{mg} / \mathrm{dl})$ than the positive control.

Statistical analysis of those results gave significant differences in all treatments between blood glucose level of administered extract doses versus period $(\mathrm{P}=<0.05)$ (Figure 1). Treatments of doses $20-50 \mathrm{mg} / 200 \mathrm{BW}$ also gave the anti-diuretic effect on testing animals. The research showed that the administered dose of $30 \mathrm{mg} / 200 \mathrm{~g} \mathrm{BW}$ of the ethanol extract equals the positive control.

The mechanism of ethanol extract of sappan wood in decreased blood glucose level could be explained as follows:

1. Fructose-2, 6-bisphosphate (F-2, 6-BP), a gluconeogenic intermediate, plays a critical role in hepatic glucose output by regulating gluconeogenesis and glycolysis in the liver. Increased hepatic glucose output is one of the major mechanisms of hyperglycemia in diabetic animal patients.

2. Brazilin, an active component of sappan, decreases blood glucose in diabetic white rat animals

In this study, the effect of brazilin on gluconeogenic intermediate production and enzyme activity were examined to investigate the hypoglycemic mechanism of brazilin. As said by You et al. (2005) brazilin has increased the production of F-2,6-BP in hepatocytes by elevating intracellular levels of fructose-6phosphate (F-6-P) and hexose-6-phosphate (H-6-P) to enhance insulin receptor function and lower blood sugar.

As reference, Jafri, et.al. (2000) reported that the oral administration of Punica granatum L., flower aqueous-ethanolic (50\%, v:v) extract led to significant blood glucose lowering effect in normal, glucose-fed hyperglycemic and alloxaninduced diabetic rats. This effect of the extract reached maximum at $400 \mathrm{mg} / \mathrm{kg}$ B.W. 


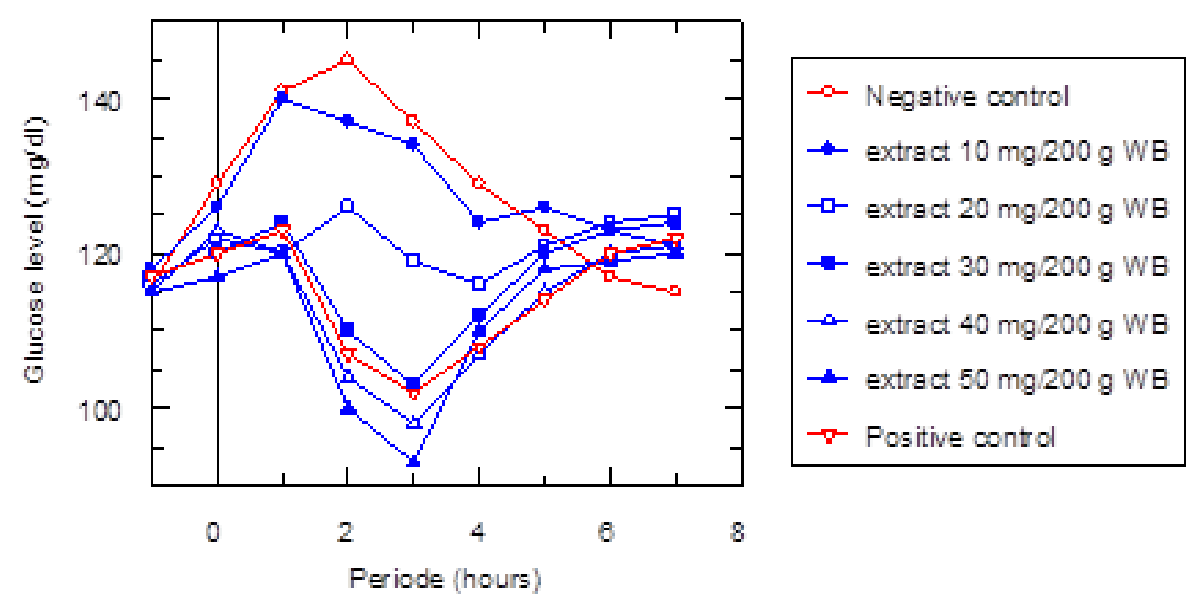

Figure 1. Curve of glucose level in rat blood after treatment

\section{CONCLUSION}

This experiment showed that all of the treatment doses decreased the blood glucose level. The treatment of ethanol extract of sappan wood by administering doses gave remarkable effect of blood glucose level in white rats and also reduced glucose level in blood compared to negative control and positive control.

Treatment of dose $30 \mathrm{mg} / 200 \mathrm{~g} \mathrm{BW}$ (103 $\mathrm{mg} / \mathrm{dl}$ ) gave similar effect to positive control $(102 \mathrm{mg} / \mathrm{dl})$, while dose of $50 \mathrm{mg} / 200 \mathrm{~g} \mathrm{BW}$ gave lower blood glucose level $(93 \mathrm{mg} / \mathrm{dl})$ than positive control.

As the base material for a standard preparation of fitofarmaka, its effectiveness needs to be advancely tested for quality, safety and efficacy. Further scientific research is still needed to obtain a practical and an effective drug dosage form.

\section{ACKNOWLEDGEMENT}

The authors thanks to Prof. Dr. H. Chairul, Apt., and Dr. Tri Murningsih at Natural Products Laboratory, Botany Division, and Research Center for Biology- Indonesia Institute of Science for their assistance in this research.

\section{REFERENCES}

Amrun, M., \& Umiyah. (2005). Pengujian antiradikal bebas Difenilpikril Hidrazil (DPPH) ekstrak buah kenitu (Chrysophyllum cainito L.) dari daerah sekitar Jember. Jurnal Ilmu Dasar, 6(2), 110-114.

Aulia, F. X. (2002). ). Stabilitas zat warna kayu secang (Caesalpinia sappan Linn.) terbadap subu dan $p H$ (Skripsi). Universitas Islam Negeri.

Badami, S., Moorkoth, S., Rai, S. R., Elango, L., \& Bhojraj, S. (2003). Antioxidant activity of Caesalpinia sappan heartwood. Biol. Pharm. Bulletin, 26(11), 1534 - 1537.

Badami, S., Moorkoth, S., \& Suresh, B. (2004). Caesalpinia sappan a medical and dye yielding plant. Natural Products Radiance, 3(2), 75-82.

Chairul. (2003). Identifikasi secara cepat bahan bioaktif pada tumbuhan di lapangan. Berita Biologi, 6(4), 621-629.

Hakim, E. H., Syah, Y. ., Juliawati, L. D., \& Mujahidin, D. (2008). Aktivitas antioksidan dan inhibitor tirosinase beberapa stilbenoid dari tumbuhan Moraceae dan Dipterocarpaceae yang potensial untuk bahan kosmetik. Jurnal Matematika dan Sains, 13(2), 33-42.

Jafri, M., Aslam, M., Javed, K., \& Singh, S. (2000). Effect of Punica granatum Linn. (flowers) on blood glucose level in normal and alloxan-induced diabetic rats. Journal of Ethnopharmacology, 70, 309-314.

Malole, M. B. M., \& Purnomo, C. S. U. (1989.). 
Buku panduan penggunaan hewan-hewan percobaan di laboratorium Institut Pertanian Bogor (p. 94). Bogor.

Pranoto, G. (1999). Potensi dan strategi industrilisasi obat tradisional Indonesia, dalam Seminar Nasional Pendayagunaan Potensi Obat Tradisional Indonesia sebagai Unsur dalam Sistem Kesehatan (p. 86). Jakarta: BPPT.

Praptiwi, Harapini, M., \& Astuti, I. (2006). Nilai peroksida Aglaia argentea Blume, A. silvestria (M. Roemer) Merr., dan A. tomentosa Teijsm. \& Binn. Biodiversitas, 7(3), 242-244.

Prawirosujanto, S. (1977). Materia medika Indonesia (pp. 63-70). Jakarta: Depkes RI.

Rohman, A., Riyanto, S., \& Utari, D. (2006). Aktivitas antioksidan, kandungan fenolik total dan kandungan flavonoid total ekstrak etil asetat buah mengkudu serta fraksi-fraksinya. Majalah Farmasi Indonesia, 17(3), 136-142.

Sudjana. (1982). Disain dan analisis eksperimen (pp. 18-40). Bandung: Tarsito.

Sugati, S. (1981). Inventarisasi tanaman obat Indonesia (pp. 90-91). Jakarta: Balitbangkes Depkes RI.

Takaoka, M., \& Tagakaki, Y. (1995). Effect of the crude drugs on $\beta$-hexosaminidase release from rat basophilic leukemia (RBL-2H3) cells. Nat. Med, 49(3), 346-349.

Walujo, E. B. (2008). Review: Research ethnobotany in indonesia and the future perspectives. Jurnal Biodiversitas, 9(1), 59-63.

World Conservation Monitoring Centre. (1998). Caesalpinia sappan. IUCN Red List of Threatened Species. Version 2009. Retrieved February 11, 2010, from http://www.iucnredlist.org/

Xu, H.-X., \& Lee, S. F. (2004). The antibacterial principle of Caesalpina sappan. Pbytother. Res., 18, 647-651.

You, E. J., Khil, L. Y., Kwak, W. J., Won, H. S., Chae, S. H., Lee, B. H., \& Moon, C. K. (2005). Effects of brazilin on the production of fructose-2,6bisphosphate in rat hepatocytes. Journal of Ethnopharmacology, 102(1), 53-57. 